\title{
RATE OF INCREASING CONCENTRATIONS OF ATMOSPHERIC CARBON DIOXIDE CONTROLLED BY NATURAL TEMPERATURE VARIATIONS
}

\author{
Fred Goldberg, Dr Tech \\ Box 1210, SE-181 24 Lidingö, Sweden \\ Email:Fred@materialdata.se
}

\begin{abstract}
Studies of the temperature anomalies during the last 27 years show a close relationship with the varying increase of $\mathrm{CO}_{2}$ in the atmosphere. Volcanic eruptions and La Niñas reduce $\mathrm{CO}_{2}$ values and $\mathrm{El}$ Niños increase them. This close relationship strongly indicates that ocean temperatures and the solubility of $\mathrm{CO}_{2}$ in seawater control the amount of $\mathrm{CO}_{2}$ being absorbed or released by the oceans. It is therefore likely that the increased $\mathrm{CO}_{2}$ concentration in the atmosphere is due to a natural global warming and that $\mathrm{CO}_{2}$ produced through fossil fuel combustion by humans can not disrupt this balance. An advanced statistical multiregression analysis confirms this conclusion. Therefore it is likely that there is no anthropogenic climate change on a global scale. The natural exchange of $\mathrm{CO}_{2}$ between ocean, biomass on land and the atmosphere is very large. In only four to five years all the $\mathrm{CO}_{2}$ in the atmosphere has been recycled through the oceans and the biomass system. The annual anthropogenic human production of $\mathrm{CO}_{2}$ is neutralized by nature in as little as 12 days. Recent studies of the solar forcing, changes in cosmic radiation and its role in cloud formations explain the global warming that has taken place since 1910.
\end{abstract}

Key words: $\mathrm{CO}_{2}$ emissions, atmosphere, natural versus anthropogenic global warming, climate change and oceans.

\section{INTRODUCTION}

$\mathrm{CO}_{2}$ is an essential gas for all life on Earth. It is a non-toxic, colourless and odourless gas which is needed by all plants for their photosynthesis. The plant absorbs $\mathrm{CO}_{2}$ through its stomata cells on the underside of its leaves or needles and together with sunlight (=energy) and water carbohydrate (sugar) products are formed. A by-product is oxygen, a gas of vital importance for all life-forms on land. Most living life forms on Earth are hence dependent of $\mathrm{CO}_{2}$. The first life forms on Earth were algae or phytoplankton in the oceans consuming large volumes of $\mathrm{CO}_{2}$ for their photosynthesis and building of shells [1].

It has been proposed that, when Earth was formed 4,5 billion years ago the atmosphere consisted of $80 \% \mathrm{CO}_{2}, 10 \%$ water and $10 \%$ nitrogen. Over the billions of years acidic rains containing carbonic acid have dissolved the silicates on the surface of Earth resulting in carbonate products being collected on the bottom of the seas. Here some of these carbonate products have transformed into limestone. Today the concentration of $\mathrm{CO}_{2}$ is $380 \mathrm{ppmv}$ or $0,038 \%$ of the atmosphere. All the coal found around the world originates from the $\mathrm{CO}_{2}$ in the atmosphere. During the Carboniferous period 300 Mya it is believed that the $\mathrm{CO}_{2}$ concentration in the atmosphere was $350 \mathrm{ppmv}$. It subsequently increased to several thousand ppmv due to a higher global temperature of approx. $22^{\circ}$ resulting in warmer oceans which releases $\mathrm{CO}_{2}$ into the atmosphere. Today's average global temperature is estimated to be $14,5^{\circ}$ [2].

$\mathrm{CO}_{2}$ is easily dissolved in seawater and the solubility is temperature dependant. Colder water can dissolve more $\mathrm{CO}_{2}$ and increasing water temperatures reduce the solubility, figure $1 . \mathrm{CO}_{2}$ is dissolved in water and establishes an equilibrium with the atmosphere according to Henry's Law. When e.g. sparkling mineral water is produced, the water is cooled to $5^{\circ} \mathrm{C}$ and $\mathrm{CO}_{2}$ gas 
is freely bubbled through the flowing water. In less than a minute the cold water has absorbed 3 litres of $\mathrm{CO}_{2}$ gas needed for a 1 litre bottle of mineral or soda water.

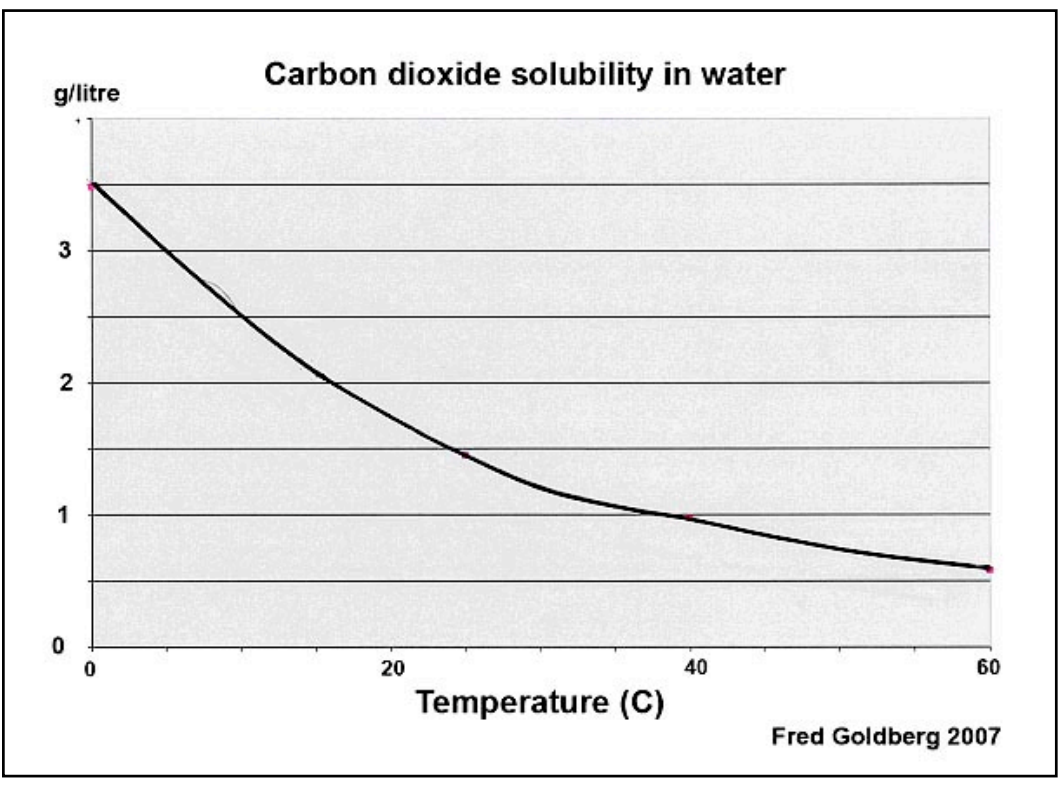

Figure 1. Diagram showing the solubility of $\mathrm{CO} 2$ in water. [3].

Open ocean water in equilibrium with the atmosphere at $0^{\circ} \mathrm{C}$ contains about 2200 micromoles/liter $\mathrm{CO}_{2}$, which is about 75 times as much as that in pure water. The seawater has a $\mathrm{pH}$ of about 8.0 (similar to our blood), and about $1 \%$ of the dissolved $\mathrm{CO}_{2}$ in seawater is in the form of $\left(\mathrm{CO}_{2}\right)$ aq or $\mathrm{H}_{2} \mathrm{CO}_{3}$, and $97 \%$ is in the form of $\mathrm{HCO}_{3}-$. Since the degree of ionic dissociation changes with $\mathrm{pH}$, the solubility of $\mathrm{CO}_{2}$ in seawater is a function of not only temperature but also $\mathrm{pH},[4]$.

Henry's Law says that $\mathrm{CO}_{2}$ is in equilibrium between the air and water at $25^{\circ} \mathrm{C}$ when approximately $1 / 50$ of the gas is in the air and the remaining gas is dissolved in the water. If 50 units of gas are added to the air 49 units will be dissolved into the water.

This process is also well illustrated by the ice core from Vostok Station in Antarctica. This ice core spans over 450000 years and yields the temperature and $\mathrm{CO}_{2}$ concentration, Figure 2. The temperature curve spans over four ice ages indicating a rapid warming, a short interglacial period and a long cooling period, together covering a 100000 year period. The $\mathrm{CO}_{2}$ measurements show a very similar pattern but with a slight time delay. The actual low values of the $\mathrm{CO}_{2}$ concentrations must be questioned due to the physical and chemical processes in the ice changing the original concentration of $\mathrm{CO}_{2}$ in the trapped air [5]. When the temperature rises at the end of an ice age the concentration of $\mathrm{CO}_{2}$ increases rapidly with approx. $50 \%$ or more in the atmosphere. This $\mathrm{CO}_{2}$ can only come from the oceans and during the glacial periods, when the concentration of $\mathrm{CO}_{2}$ is low the $\mathrm{CO}_{2}$ has gone back into the oceans, as the solubility for $\mathrm{CO}_{2}$ increases with colder water. It is the heating and cooling of the oceans that controls the amount of $\mathrm{CO}_{2}$ in the atmosphere. It is interesting to note in figure 2 that during the previous interglacial period it was warmer than today despite the atmospheric $\mathrm{CO}_{2}$ concentration according to ice cores being lower than today. 


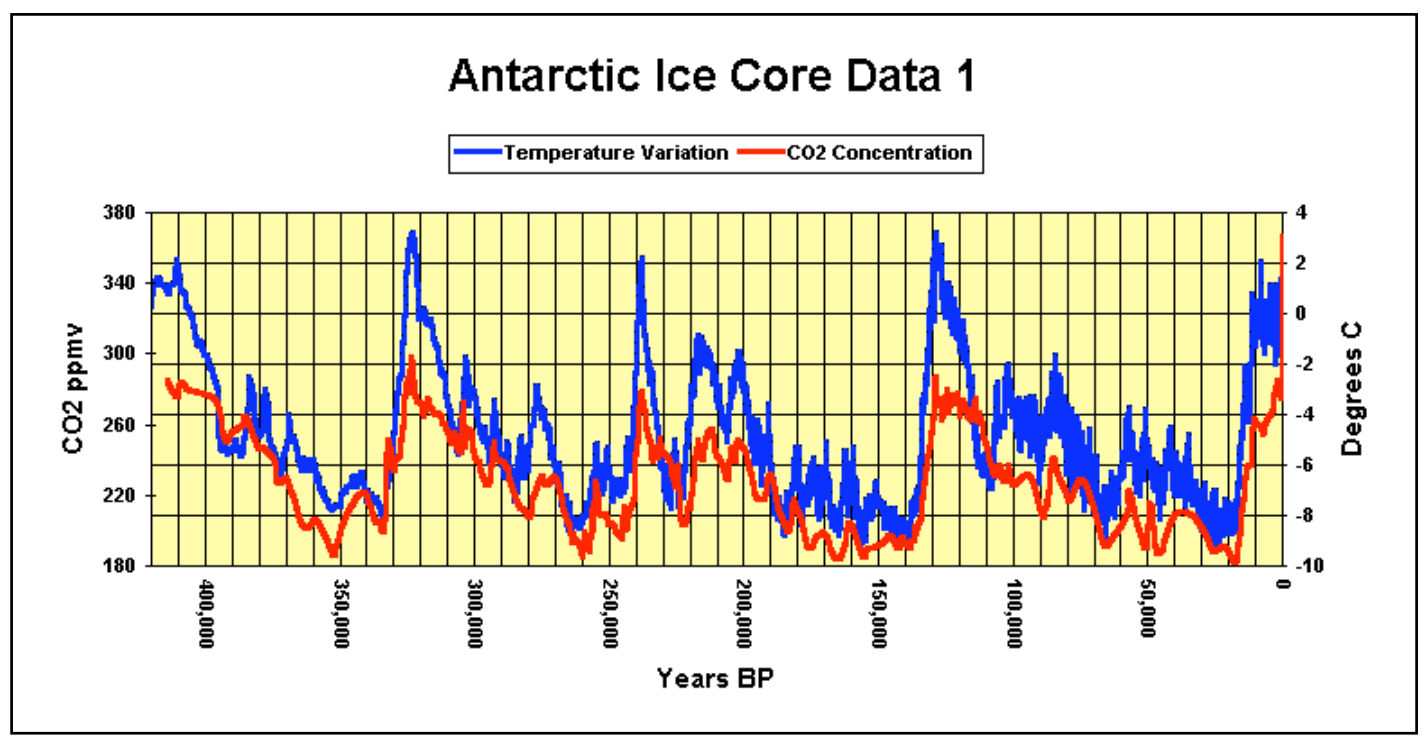

Figure 2. Historical Isotopic Temperature record from the Vostok Ice Core.( J.R. Petit et al 1999)

Today the cold waters surrounding the Antarctic continent and in and near the Arctic Ocean are absorbing $\mathrm{CO}_{2}$. Being dissolved in the colder heavier water, the $\mathrm{CO}_{2}$ rich water will eventually sink to the ocean floor and be transported around the world. The flow of cold water from the Arctic Ocean goes southward along the bottom of the Atlantic Ocean, often called "Broecker's conveyor belt". When the cold waters are mixed with warmer water and eventually surface near the Equator, the water will be warmed up, and release some of its $\mathrm{CO}_{2}$.

When $\mathrm{CO}_{2}$ is dissolved in the oceans it goes through several complicated processes forming carbonic acid, bicarbonate ions, carbonate ions and limestone. These processes are very complex due to currents of water of different temperatures, salinity and depths. Another complication is that seawater is supersaturated with calcium and other minerals which makes chemical standard equilibrium modelling extremely difficult and uncertain [6].

The oceans have a very large capacity for absorbing $\mathrm{CO}_{2}$. If all the $\mathrm{CO}_{2}$ in the atmosphere were to be dissolved in the oceans, a rough calculation indicates that only the upper $14 \mathrm{~cm}$ of water would be saturated. In addition all plants and phytoplankton in the oceans are large consumers of $\mathrm{CO}_{2}$. The movement of $\mathrm{CO}_{2}$ is a complex issue where large amounts are carried both horizontally and vertically by colder or warmer currents and by organisms moving up or down on a daily rhythm. The water surface exchanging $\mathrm{CO}_{2}$ with the atmosphere is strongly affected by rain, winds, wave action and air temperatures. The top $200 \mathrm{~m}$ of the world's ocean water store 30 times more heat than the atmosphere [7]. Between 1969 and 2000 the oceans have been warmed an average of $0,31^{\circ} \mathrm{C}$ [8].

\section{THE CARBON CYCLE}

According to measurements by the Oak Ridge National Laboratory, U S DOE, the total reservoir of $\mathrm{CO}_{2}$ in the atmosphere (expressed in carbon equivalents) is 775 Gtons, figure 3. The diagram shows that in the oceanic reservoir there is 38100 Gtons $\mathrm{C}$ of dissolved $\mathrm{CO}_{2}$, which (according to Henry's Law) fifty times more than in the atmosphere. According to the diagram the annual flux of $\mathrm{CO}_{2}$ from the oceans to the atmosphere is $90 \mathrm{Gton} \mathrm{C}$ and $92 \mathrm{Gton}$ $\mathrm{C}$ in the opposite direction. 


\section{Global Carbon Cycle (1992-1997) \\ (in GtC)}

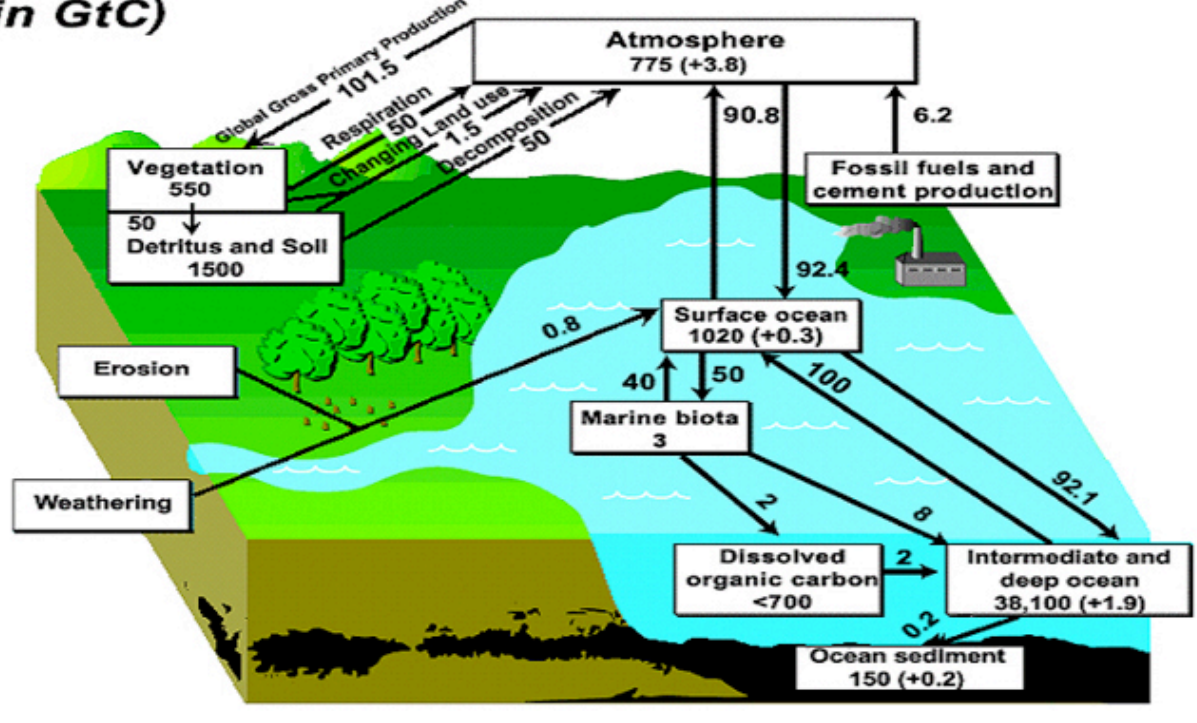

Figure 3. Global Carbon cycle diagram presented by the Carbon Dioxide Information Analysis Center at US DOE's Oak Ridge National Laboratory (ORNL).

The biomass is absorbing 101 Gton $\mathrm{C}$ per year but is also releasing the same amount due to decay processes. This shows that all the $\mathrm{CO}_{2}$ in the atmosphere $775 /(101+92)=4$ is circulated through the oceans and the biomass in approx. four years. The human contribution of $\mathrm{CO}_{2}$ to the atmosphere is estimated to 7-8 Gton $\mathrm{C}$ per year, which is one percent of the existing $\mathrm{CO}_{2}$ in the atmosphere. If we add the absorption of $\mathrm{CO}_{2}$ into the oceans and biomass of $92+101=$ 193 Gton C, we can calculate that the annual human contribution corresponds to only 12 days of natural turnover. This shows that human emissions of $\mathrm{CO}_{2}$ are a very small part of the total natural circulation of $\mathrm{CO}_{2}$.

\section{IS THE INCREASED $\mathrm{CO}_{2}$ IN THE ATMOSPHERE NATURAL OR NOT?}

It is a fact that there has been an increase of the global temperature during a large part of the 20th century and there has been an increase of the $\mathrm{CO}_{2}$ concentration in the atmosphere during the second half of the past century. Has the concentration of $\mathrm{CO}_{2}$ in the atmosphere increased as a result of fossil fuel burning? Has the increased concentration of $\mathrm{CO}_{2}$ in the atmosphere caused a global warming due to the greenhouse effect? The answer to both these questions are no. The reasons for these answers are as follows.

At the NOAA internet site http://www.emdl.noaa.gov./cds/index.php\#global the mean annual global increase of $\mathrm{CO}_{2}$ in the atmosphere can be found . At internet address

http://vortex.nsstc.uah.edu/public/msu/t2lt/tltglhmam 5.2 satellite tropospheric temperature data (MSU) from University of Alabama in Huntsville is found. These satellite temperature measurements are the most accurate as they do not contain any urban effects which most stations on land surface do. The mean annual global increase of $\mathrm{CO}_{2}$ in the atmosphere can be found from a series of different stations from 1979 to 2005. In table 1. the annual increase of $\mathrm{CO}_{2}$, temperature anomalies and the man-made emissions of $\mathrm{CO}_{2}$ are listed. When looking at these numbers, the smallest increase between 1979 and 2006 was found during years 19911992. During this time interval the huge volcanic eruption of Pinatubo took place. At the same time these two years 1991-1992 had the smallest increase of $\mathrm{CO}_{2}$ in the atmosphere. How is this possible? The explanation is found in the fact that the volcanic eruption of Pinatubo had a strong cooling effect around the world for more than a year, because volcanic 
eruptions in addition to large quantities of $\mathrm{CO}_{2}$ also contribute large quantities of ashes, sulphuric acids and other aerosol particles into the atmosphere. This cooling effect reduces the oceans' ability in the tropics to release $\mathrm{CO}_{2}$ into the atmosphere and this explains why the two years 1991-1992 had the smallest increase of CO2 during the whole 25 year period.

\begin{tabular}{|c|c|c|c|}
\hline \multicolumn{2}{|c|}{$\begin{array}{l}\text { CO2 average increase } \\
\text { per year }\end{array}$} & Temp anomaly & $\begin{array}{c}\text { Emissions } \\
\text { Gton C }\end{array}$ \\
\hline Year & ppmv/year & $\delta^{\circ} \mathrm{C}$ & \\
\hline 1979 & 1.64 & -0.074 & 5.403 \\
\hline 1980 & 1.67 & 0.088 & 5.348 \\
\hline 1981 & 1.08 & 0.052 & 5.186 \\
\hline 1982 & 0.99 & -0.154 & 5.144 \\
\hline 1983 & 1.83 & 0.036 & 5.126 \\
\hline 1984 & 1.32 & -0.257 & 5.308 \\
\hline 1985 & 1.60 & -0.213 & 5.464 \\
\hline 1986 & 1.02 & 0.148 & 5.629 \\
\hline 1987 & 2.71 & 0.109 & 5.762 \\
\hline 1988 & 2.24 & 0.109 & 5.992 \\
\hline 1989 & 1.36 & -0.110 & 6.106 \\
\hline 1990 & 1.27 & 0.074 & 6.196 \\
\hline 1991 & 0.82 & 0.116 & 6.312 \\
\hline 1992 & 0.64 & -0.192 & 6.187 \\
\hline 1993 & 1.13 & 0.149 & 6.203 \\
\hline 1994 & 1.62 & -0.012 & 6.344 \\
\hline 1995 & 2.03 & 0.124 & 6.487 \\
\hline 1996 & 1.10 & 0.020 & 6.649 \\
\hline 1997 & 1.96 & 0.047 & 6.840 \\
\hline 1998 & 2.91 & 0.512 & 6.788 \\
\hline 1999 & 1.37 & 0.039 & 6.804 \\
\hline 2000 & 1.24 & 0.034 & 6.981 \\
\hline 2001 & 1.86 & 0.200 & 7.116 \\
\hline 2002 & 2.36 & 0.313 & 7.167 \\
\hline 2003 & 2.23 & 0.272 & 7.504 \\
\hline 2004 & 1.65 & 0.192 & 7.910 \\
\hline 2005 & 2.42 & 0.328 & 8.098 \\
\hline 2006 & 1.72 & 0.275 & 8.329 \\
\hline
\end{tabular}

Table 1. The first column shows the total (natural and man-made) annual increase of $\mathrm{CO}_{2}$ in the atmosphere, the second column shows the temperature deviations from its mean value between 1951 to 1980 and the third column shows the world's total annual anthropogenic emissions according to the Energy and Environment Data Reference Bank.

http://www.iaea.org/inisnkm/nkm/aws/eedrb/

Data for human emissions 2005 and 2006 estimated by extrapolation of the trend 2000-2004.

The slow natural increase of $\mathrm{CO}_{2}$ during the last 27 years has low points in 1982 and 19911992. These points coincide with the eruptions of the Mexican volcano El Chichon and the Philippine volcano Pinatubo. The annual increase of $\mathrm{CO}_{2}$ in the atmosphere bears no relation with the amount of man-made $\mathrm{CO}_{2}$ released, figure 4. This fact is also evident when we look at the year 1998. Here we find that the highest increase of $\mathrm{CO}_{2}$ coincides with the super El Niño, which warmed the Earth atmosphere approx 0,5-0,6 $\mathrm{C}$ above normal and also the oceans. figure 5 . 


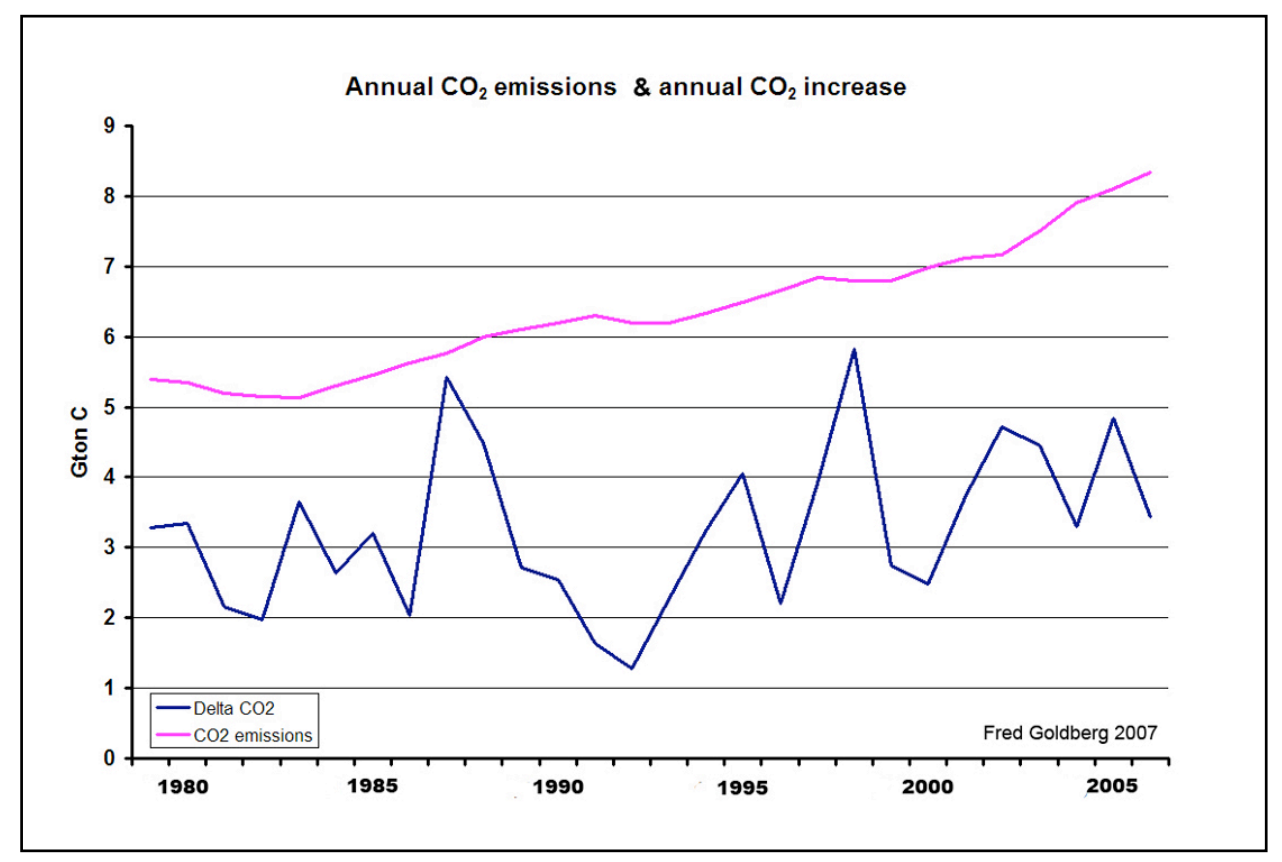

Figure 4. Annual total emissions of anthropogenic carbon dioxide in Gton C (red line) compared with the annual increase of $\mathrm{CO}_{2}$ in the atmosphere between 1979 and 2006 (blue line). The area between the two lines show how much $\mathrm{CO}_{2}$ that was absorbed primarily by the oceans.

When combining the temperature anomalies during the last 27 years with the annual increases of atmospheric $\mathrm{CO}_{2}$ during the same period, figure 6 ,

(http://www.emdl.noaa.gov./cds/index.php\#global) we see a striking similarity in the variations over time. This shows that the warming and cooling of the ocean waters control how much $\mathrm{CO}_{2}$ is exchanged with atmosphere and thereby controlling the concentration of atmospheric $\mathrm{CO}_{2}$. It is obvious that when the oceans are cooled, in this case due to volcanic eruptions or La Niña events, they release less $\mathrm{CO}_{2}$ and when it was an extremely warm year, due to an El Niño, the oceans release more $\mathrm{CO}_{2}$.

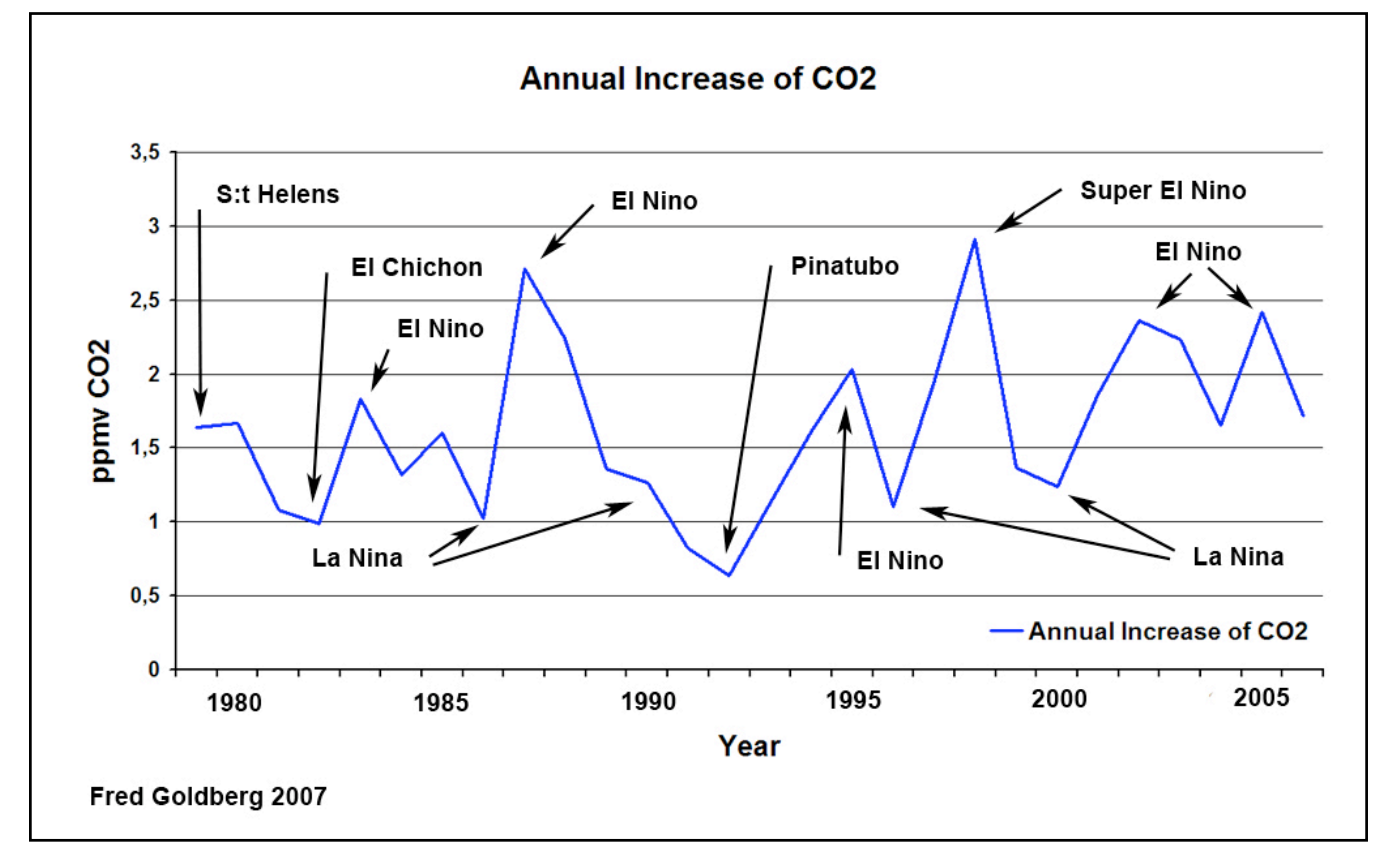

Figure 5 . The increase of atmospheric carbon dioxide concentration year by year from 1979 to 2006. The $\mathrm{CO}_{2}$ increase varies by cooling caused by volcanic eruptions or La Niñas or by warming due to El Niños. 


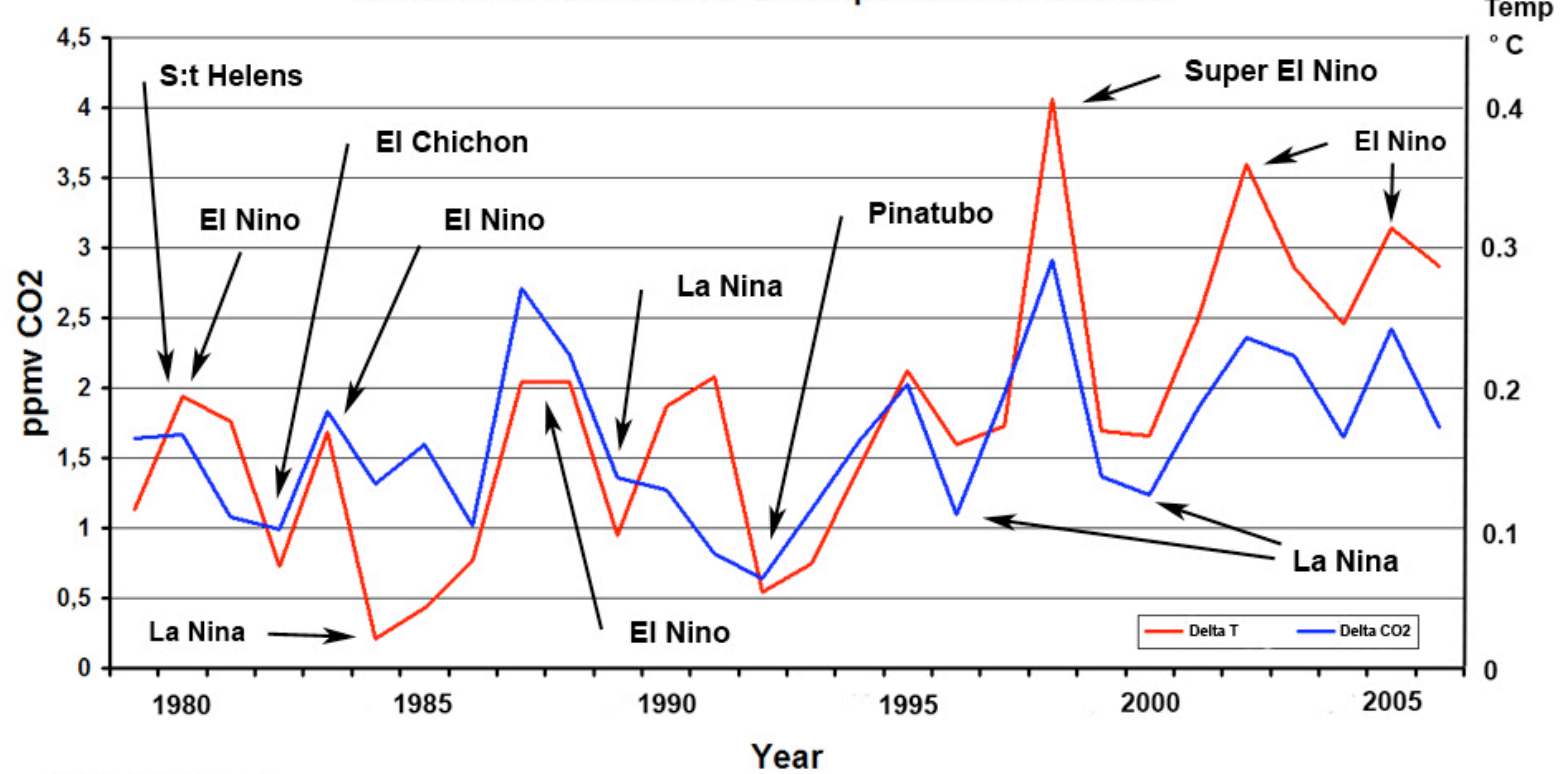

Fred Goldberg 2007

Figure 6. The annual $\mathrm{CO}_{2}$ increases and the temperature anomalies 1979-2006

The discrepancy between $\mathrm{CO}_{2}$ and temperature in 1980 is explained by an El Niño and a volcanic eruption of Mt S:t Helens taking place simultaneously.

We can see from these two figures 5 and 6 that during the measured time 1979 to 2006 there has been a continued natural increase in temperature causing a continued increase of $\mathrm{CO}_{2}$ released into the atmosphere. This implies that temperature variations caused by El Niños, La Niñas, volcanic eruptions, varying cloud formations and ultimately the varying solar irradiation control the amount of $\mathrm{CO}_{2}$ which is leaving or being absorbed by the oceans [9]. Between 1979 and 2006 there has been a continuously increasing concentration of $\mathrm{CO}_{2}$ in the atmosphere and at the same time the temperature anomaly in diagram 6 shows an average global warming of $0,2^{\circ} \mathrm{C}$.

\section{STATISTICAL ANALYSIS}

A multiple regression analysis on the data in table 1, using Multiple Regression with Backward Elimination between year, MSU, Emissions and annual $\mathrm{CO}_{2}$ increases, confirms a highly significant correlation between temperature anomalies and annual $\mathrm{CO}_{2}$ increases $(\mathrm{P}<0.0001)$ and no significant correlation between $\mathrm{CO}_{2}$ increases and human caused annual $\mathrm{CO}_{2}$ emissions $(\mathrm{P}>0.10)$.

The method Multiple Regression with Backward Elimination Procedure is described in the book Applied Regression Analysis by N.R. Draper and H.Smith 1967.

It is a very surprising result, establishing the fact that the man-made emissions are insignificant and therefore have no influence on the $\mathrm{CO} 2$ concentration in the atmosphere. 


\section{DISCUSSION}

\subsection{Is there other evidence for the increase of carbon dioxide concentration in the atmosphere being natural?}

As just mentioned, the $\mathrm{CO}_{2}$ concentration increased between 1979 and 2006 due to natural causes. This means that a.o. the global temperature was above a certain equilibrium level. At what temperature level would the $\mathrm{CO}_{2}$ stop leaving the oceans? To answer this question is difficult as the global temperature measurements are very complex and difficult to define. When we look at IPCC (United Nations Intergovernmental Panel on Climate Change), figure 7, showing the global temperatures measured over the last 140 years, we find a period between 1940 and 1975 when the global temperature was slowly decreasing approx. 0,3 C. Between 1955 and 1959 there were $19 \mathrm{CO}_{2}$ measurement stations set up around Scandinavia by Walter Bischof [10]. His results showed that the mean monthly $\mathrm{CO}_{2}$ concentration in the atmosphere could vary by $50-60$ ppmv during one year. We also find that the annual mean values varied strongly, but there is no upward trend during this period, figure 8 . This suggests that the global temperatures and the release of $\mathrm{CO}_{2}$ from the oceans were in equilibrium during the period of 1955-1959.

Since 1975 there has been a natural climate improvement (warming) resulting in a larger annual release of $\mathrm{CO}_{2}$ from the warm oceans than is being absorbed by the cold oceans. Therefore the concentration of $\mathrm{CO} 2$ in the atmosphere has slowly been increasing. As shown in chapter 5 this increase has no connection with human emissions but is the result of a general warming of the oceans reducing their solubility of $\mathrm{CO}_{2}$.

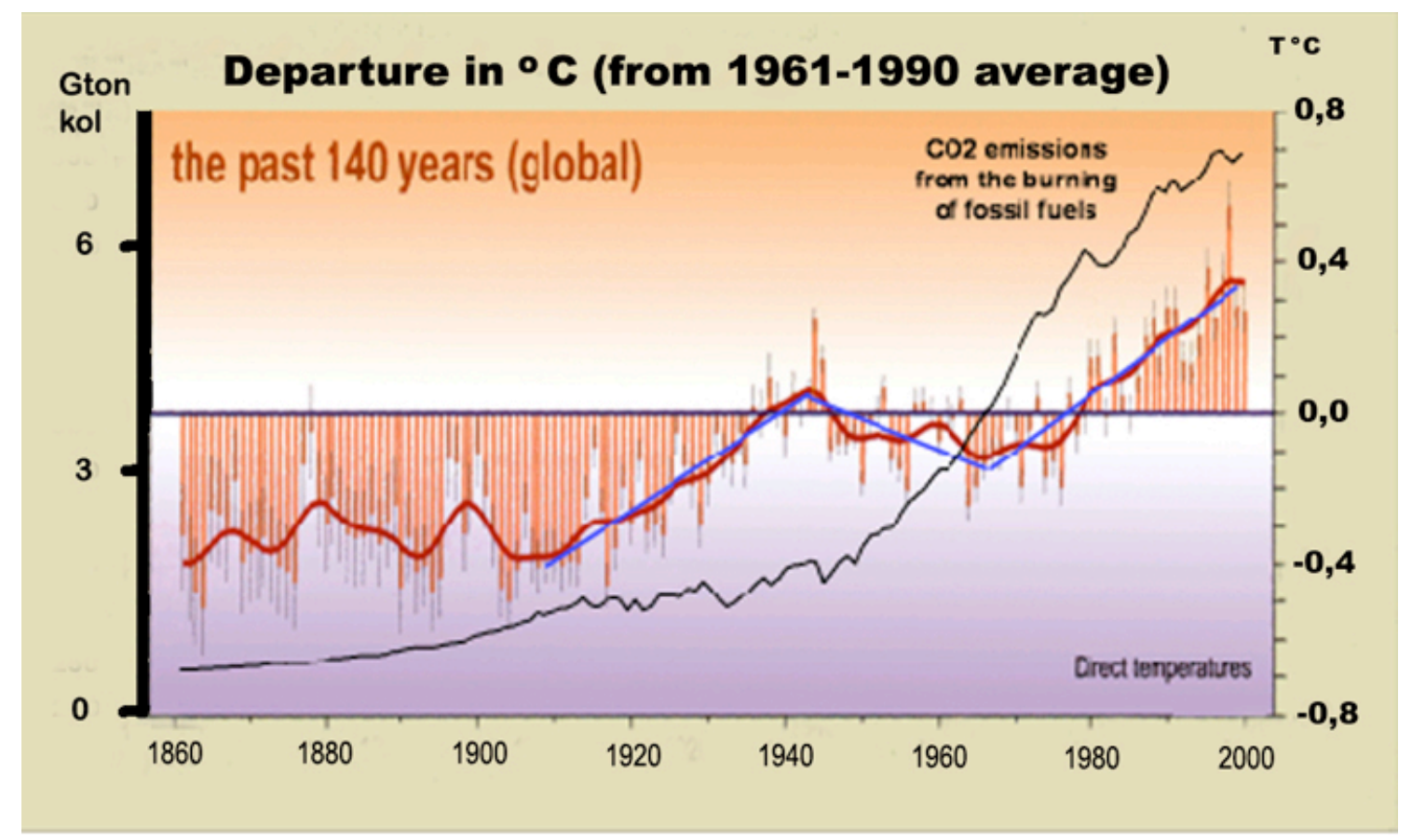

Figure 7. Global temperature anomalies from 1860 to 2000 show a cooling period from 1940 to 1975 despite large emissions of $\mathrm{CO}_{2}$. [11].

\subsection{Is Carbon dioxide from fossil fuel burning changing the atmospheric composition?} According to figure 9 in the IPCC report 2001, chapter 3.3.1 Geological History of Atmospheric $\mathrm{CO}_{2}$ the annual human emissions of $\mathrm{CO}_{2}$ are constantly increasing. The same diagram also shows the atmospheric $\mathrm{CO}_{2}$ growth rates annually and monthly. It seems very strange that the rate of increasing $\mathrm{CO}_{2}$ in the atmosphere varies considerably from year to year despite the fact that the anthropogenic release of $\mathrm{CO}_{2}$ shows a steady increase. This indicates that the anthropogenic $\mathrm{CO}_{2}$ bears no relation to the variations of the $\mathrm{CO}_{2}$ growth rates in the atmosphere as verified by the multiple regression analysis. The $\mathrm{CO}_{2}$ anomalies in 
the atmosphere, as illustrated in figures 4-6, are the result of the global temperature variations due to volcanic eruptions, El Niños and La Niñas.

During the two years 1991-1992 the $\mathrm{CO}_{2}$ concentration increased 1,46 ppmv in the atmosphere which corresponds to $3 \mathrm{Gton} \mathrm{C}$ in the form of $\mathrm{CO}_{2}$. During the same time period the human fossil fuel burning sent 12,5 Gton $\mathrm{C}$ into the atmosphere. What happened to the remaining 9,5 Gton $C$ that did not contribute to the increased concentration in the atmosphere?

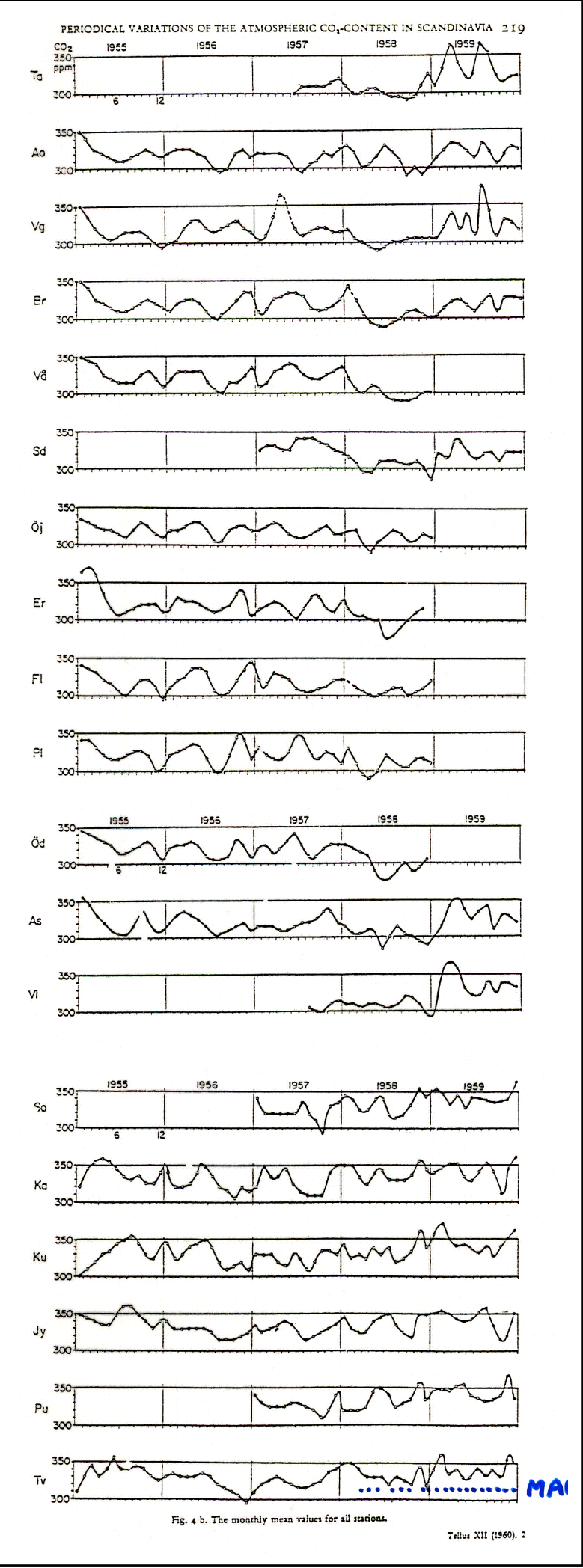

The missing 9,5 Gton $\mathrm{C}$ are apparently all dissolved by the oceans as there is no evidence that the amount of biomass on land has changed over the same time period. The reactions that take place with $\mathrm{CO}_{2}$ in the oceans are very complex between a series of mineral salts and with a diverse biomass in the oceans 5 times larger than on land according to Eric Olausson [12] .

Figure 8. Excellent chemical carbon dioxide measurements at 19 stations in Scandinavia for 1955-1959, Bischof [10] show no increasing trend of carbon dioxide concentrations in the atmosphere. The dotted line shows the measurements at Mauna Loa by Keeling being quite different because of his new measurement method using IR-techniques. 
6.3 Is it a coincidence that the cause of annual increases of carbon dioxide and the annual temperature anomalies are matching each other in figure 6?

The answer is almost certainly no. The reason is that the values in both curves are based on a very large amount of data. The number of temperature measurements are in the range of 65 Mil. and the $\mathrm{CO}_{2}$ measurements are in the range of 100000 .

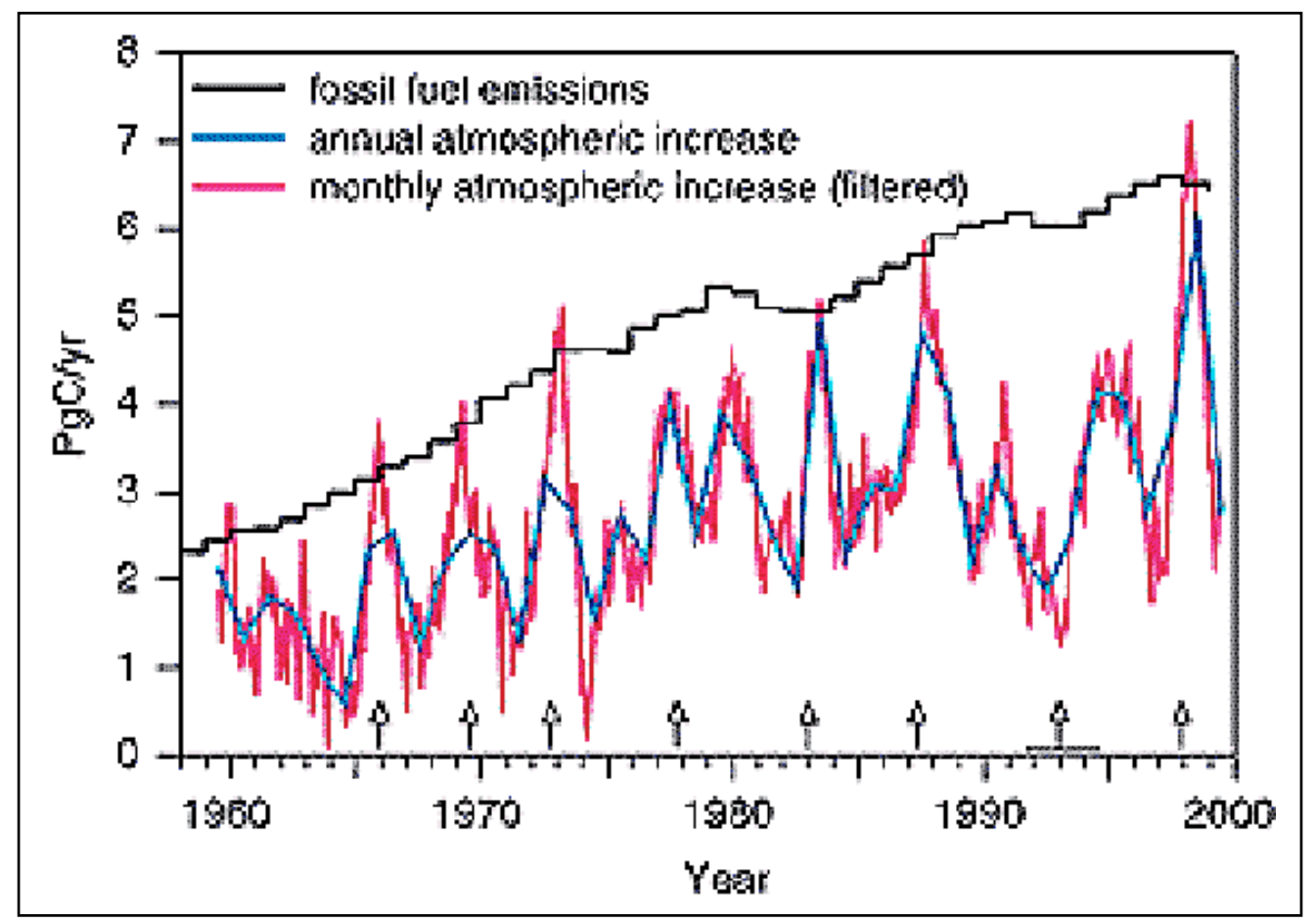

Figure 9. The increase of fossil fuel emitted $\mathrm{CO}_{2}$ versus the increase of Carbon dioxide concentration in the atmosphere. [13].

\subsection{Has the atmospheric carbon dioxide concentration during the last 1000 years been lower or higher than today?}

During the second half of the 19th century the $\mathrm{CO}_{2}$ concentration in the atmosphere was accurately measured with wet chemistry methods. These measurement often recorded values up to $550 \mathrm{ppmv}$ in the atmosphere. These measurements have been ignored by IPCC. It is, however, also possible to find proxy data for earlier atmospheric $\mathrm{CO}_{2}$ concentrations depending on the number of stomata cells in plants. A Dutch team led by L. Kouwenberg [14] has studied samples of the plant Tsuga heterophylla up to 1200 years of age. Their diagram, figure 10 , shows that the number of stomata cells have strongly varied over the years, demonstrating that the $\mathrm{CO}_{2}$ in the atmosphere also has changed considerably over the years. In the diagram is also a temperature curve inserted showing the medieval warm period and the little ice age. These temperature variations match the variation of stomata cells with a time delay of approx. 80 years. We can also see from the diagram that the $\mathrm{CO}_{2}$ concentrations in the atmosphere fluctuated naturally by almost $100 \mathrm{ppm}$ several times over the last 1000 years. The stomata cell data as well as direct measurements show that atmospheric $\mathrm{CO} 2$ concentration repeatedly varied prior to the recent large emission of $\mathrm{CO}_{2}$ in the last century. The variation of the $\mathrm{CO}_{2}$ concentration prior to the last century can only have been induced by natural causes. But the magnitude of the variation in atmospheric $\mathrm{CO}_{2}$ concentration is not observed to have changed during the last century. This lack of change of the magnitude of variation in atmospheric $\mathrm{CO}_{2}$ concentration is strong evidence indicating that the increased $\mathrm{CO}_{2}$ concentration in the atmosphere during the last century is due to natural causes. At the very least, there is no reason to suppose that natural causes are not responsible for the increased atmospheric $\mathrm{CO}_{2}$ concentration during the last century. 
We also see varying $\mathrm{CO}_{2}$ concentrations during the last 200 years, up to more than $550 \mathrm{ppmv}$, considerably higher than measured today, analysed by wet chemistry. [6,15]. If all $\mathrm{CO}_{2}$ measurements are taken into account from the last 192 years the average value is found to be 335 ppmv, with three peaks of 5 year averages of 440 ppmv in 1820, 390 ppmv in 1855 and 440 ppmv about 1945, [16].

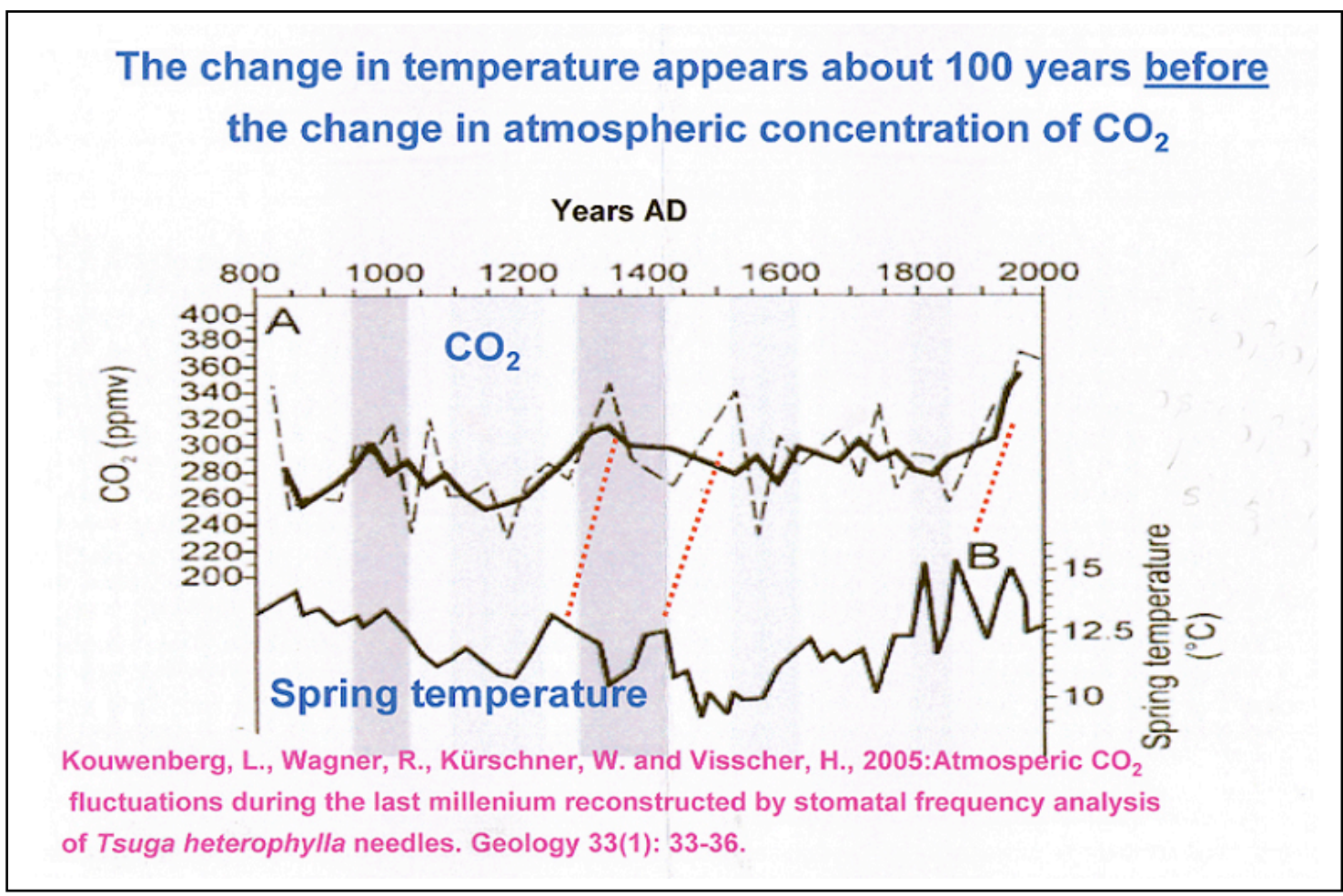

Figure 10. Reconstructed CO2 concentrations based on stomata frequency counts from the needles of the conifer Tsuga heterphylla for A.D. 800-2000. [14].

The stomata cell studies show that there have never been a preindustrial low level of $\mathrm{CO}_{2}$ as frequently stated by IPCC and others. The real increase of $\mathrm{CO}_{2}$ over the last hundred years has therefore been from a level of approx. 335 ppmv $\mathrm{CO}_{2}$ and amounts to $45 \mathrm{ppmv}$, an increase of $12 \%$ and not $30 \%$.

\section{THE EIGHT EVIDENCES THAT MAN-MADE CO $\mathrm{O}_{2}$ EMISSIONS HAVE NOT AFFECTED THE CLIMATE}

\subsection{The first piece of evidence}

A correlation (Chapter 5) between the annual increase of the $\mathrm{CO}_{2}$ concentration in the atmosphere and the mean annual global temperature anomalies was demonstrated and human emissions were found to be insignificant. The level of $\mathrm{CO}_{2}$ in the atmosphere reaches in a very short time an equilibrium with the $\mathrm{CO}_{2}$ concentration in the oceans when ocean temperatures are changing or when $\mathrm{CO}_{2}$ concentrations in the atmosphere change. This has also been verified by measuring the reduction of Carbon-14 isotopes in the atmosphere after the Soviet nuclear testing activities on Novaja Zemja in the 1960-ies [17].

The additional greenhouse effect caused by man-made emissions (which amounts to $1 \%$ of the total $\mathrm{CO}_{2}$ concentration in the atmosphere as earlier reported) amounts to $1 \%$ of $1 \%$ of 
the total greenhouse effect in the atmosphere resulting in a total of $0,01 \%$. This is too insignificant to be measured due to the large natural variations.

Of the total greenhouse effect on Earth $98 \%$ is caused by water vapour, $1 \% \mathrm{CO}_{2}$ and $1 \%$ by the remaining greenhouse gases. [18,19].

\subsection{The second piece of evidence}

During 1940 and 1975 there was a Northern hemisphere cooling and at the same time there was a rapid increase of $\mathrm{CO}_{2}$ emitted into the atmosphere during World War II and the rapidly increasing industrial development thereafter. Despite this there was a cooling of $0,3^{\circ} \mathrm{C}$. This shows that increasing emissions of $\mathrm{CO}_{2}$ have not increased the global temperature. Statements that the cooling was caused by aerosols from sulphuric acids and air pollution has not been verified. Instead the cooling is caused by less intense El Niňos during that period in combination with increased cloud cover correlated to changes in cosmic radiation according to H. Svensmark and N. Calder [9].

\subsection{The third piece of evidence}

From 1999 to 2006 there has not been any global warming in the Northern hemisphere but during this time period approximately $200 \mathrm{Gton}$ of $\mathrm{CO}_{2}$ has been added to the atmosphere. This indicates that large volumes of $\mathrm{CO}_{2}$ released into the atmosphere have not increased the temperature.

\subsection{The fourth piece of evidence}

During 1991-1992, a global cooling due to the volcanic eruption of Pinatubo was recorded. The same period showed the smallest increase of $\mathrm{CO}_{2}$ concentration in the atmosphere during the last 27 years. During 1991 and 1992 the total $\mathrm{CO}_{2}$ increase was 1,46 ppmv which corresponds to 3 Gton $\mathrm{C}$. During the same period the human emission of $\mathrm{CO}_{2}$ was approx 12,5 Gton C. Where did the other 9,5 Gton C plus the emissions from Pinatubo go? They have gone into the oceans due to the cooling of the water surface corresponding to the natural forces securing an equilibrium between $\mathrm{CO}_{2}$ in the atmosphere and in the oceans. (Chapter 1.)

\subsection{The fifth piece of evidence}

During the depression years 1929-1933 the emissions of $\mathrm{CO}_{2}$ from industries dropped 30\% but the global temperatures continued rapidly to increase. This fact disproves the idea that the greenhouse effect from $\mathrm{CO}_{2}$ is the only or major cause of increasing temperatures. [20].

\subsection{The sixth piece of evidence}

During the Roman period the average temperature was $2^{\circ} \mathrm{C}$ warmer than today (according to $\mathrm{O}_{18}$ temperature measurements of ice cores from the Greenland GISP project.) despite the lack of coal fired power plants and automobiles. This is another indication that the current global warming is natural.

\subsection{The seventh piece of evidence}

Measurements of stable carbon isotopes of atmospheric $\mathrm{CO}_{2}$ and mass balance calculations demonstrate that the lifetime of atmospheric $\mathrm{CO}_{2}$ is about 5 years. The mass of man-made $\mathrm{CO}_{2}$ in the atmosphere is $<14$ Gtons $\mathrm{C}$ which corresponds to about $2 \%$ of the total mass of $\mathrm{CO}_{2}$ in the atmosphere, [17,21].

\subsection{The eight piece of evidence}

During the previous interglacial period the temperature was approx. 6 degrees $C$ warmer than today on Greenland and 1-3 degrees $\mathrm{C}$ warmer in Antarctica according to temperature measurements in ice cores originating from Greenland and Antarctica. [22,23]. 


\section{CONCLUSIONS}

This paper has collected evidence to demonstrate that there is no connection between human emissions of $\mathrm{CO}_{2}$ and the annual increasing rates of $\mathrm{CO}_{2}$ in the atmosphere.

Furthermore it can be shown that emissions of large amounts of $\mathrm{CO}_{2}$ has not increased global temperatures and is not correlated to temperature changes.

What is evident is that natural events such as volcanic eruptions and El Niño/La Niña events change global temperatures and thereby ocean temperatures. As cold oceans absorb $\mathrm{CO}_{2}$ and warm oceans release $\mathrm{CO}_{2}$ variations of ocean areas of warm and cold water are closely related to the changes in atmospheric $\mathrm{CO}_{2}$ concentration.

\section{If the change of $\mathrm{CO}_{2}$ concentrations in the atmosphere is due to natural causes, it follows that there is no related human effect on the climate.}

On a local level, however, near urban areas, humans may have influenced the micro-climate. It is difficult to measure temperatures over land without being influenced by the urban effect. There are very few stations around the world with a long time span of measurements situated far away from growing urban centres. Today temperature data are corrected for the urban effect, but it is difficult to know if the corrections are correct or not, [24,25]. Therefore MSU temperature data from Polar orbiting satellites have been used in this report.

\section{ACKNOWLEDGEMENTS}

Firstly I would like to thank the NOAA and NASA administrations for making important climate data available to the general public, hence making this study possible. I am also grateful for the strong support I get from Professor Anders Flodström, President of the Royal Institute of Technology (KTH) in Stockholm and currently University Chancellor of Sweden. I am also deeply indebted to Professor Peter Stilbs, KTH, Professor Tom V.Segalstad, University of Oslo, Professor Wibjörn Karlén, Stockholm University, Dr Jarl Ahlbeck, Åbo Academy, Finland, Professor Boris Winterhalter, Helsinki University, Finland, Professor Fred S. Singer, SEPP, Professor Taro Takahashi, Lamont-Doherty Earth Observatory of Columbia University NY USA, Professor Martin Hertzberg, USA, Richard S. Courtney, UK, Dr Henrik Svensmark, Danish Space Center, Copenhagen, Denmark, M.Sc. Göran Tullberg, Dr Paul Brekke, Norwegian Space Center Oslo Norway and Mr Timo Hämeranta, Helsinki, Finland for providing important data and for stimulating discussions. Last but not least I am very grateful to my father, professor em. Leonard Goldberg, $\mathrm{MD}, \mathrm{PhD}$, valuable discussions and encouragement.

\section{References}

1. Chilyuk L. F. \& Chilingar G. V. On Global Forces of Nature Driving the Earth's Climate. Are Humans Involved? Environ. Geol. 2006, 50 899-910.

2. Hieb M. and Scotese C. R. Climate During the Carboniferous Period. http://geocraft.com/WVFossils/Carboniferous climate.html

3. Handbook of Chemistry and Physics, $37^{\text {th }}$ edition 1955-1956, Chemical Rubber Publishing Co. p. 496-497.

4. Takahashi, T. Doherty-Lamont Observatory, Columbia University, NY. USA Private communication 2007.

5. Jaworowski Z., Segalstad, T.V. \& Ono, N. Do Glaciers Tell a True Atmospheric $\mathrm{CO}_{2}$ Story? Science of the Total Environment 114, 227-284, $1992 .$.

6. Jaworoski Z., Segalstad T. V. \& Hisdal V. Atmospheric $\mathrm{CO}_{2}$ and Global Warming - A Critical Review. Norwegian Polar Institute, Meddelser No. $119,2^{\text {nd }}$ revised edition._Oslo 1992, $72 \mathrm{pp}$. 


\section{7. http://www.a-ce.mmu.ac.ukeae/.html}

8. NOAA News online 2000.

9. Svensmark H. \& Calder N. The Chilling Stars - A new theory of climate change. Icon Books Ltd, Cambridge 2007. ISBN -10: 1-84046-815-7

10. Bischof W. - Periodical Variations of the Atmospheric $\mathrm{CO}_{2}$ concentration in Scandinavia, Tellus XII, 1959.

11. From Illarionov and IPCC Climate Change 2001 Synthesis Report, p.49.

12. Olausson E. Långsiktiga Klimatförändringar (Long term climate changes), Kungl. Skogs och Lantbruksakademiens Tidskrift 137:8 1998 p. 12. (Swedish).

13. IPCC TAR 2001. (Third Assesment Report).

14. Kouwenberg L., Wagner R., Kürschner W. \& Visscher H. Atmospheric $\mathrm{CO}_{2}$ Fluctuations During the Last Millenium Reconstructed by Stomatal Frequency Analysis of Tsuga heterophylla needles. GEOLOGY January 2005.

15. Fonselius F., Koroleff, F. \& Wärme, K.-E. -Carbon Dioxide in the Atmosphere. Tellus 8, 1956, p. 176-183,.

16. Beck E.-G. 180 Years of Atmospheric $\mathrm{CO}_{2}$ Gas Analysis by Chemical Methods, Energy

\& Environment, volume 18 no. 2 2007. ISSN 0958-305X.

17. Segalstad T. V. -The Distribution of $\mathrm{CO}_{2}$ Between Atmosphere, Hydrosphere, and Lithosphere; minimal influence from anthropogenic $\mathrm{CO}_{2}$ on the global "Greenhouse Effect". In Emsley, J. (Ed.): The Global Warming Debate. The Report of the European Science and Environment Forum. Bourne Press Ltd., Bournemouth, Dorset, U.K. (ISBN 0952773406), 4150, 1996.

18. Raval, A. \& Ramanathan, V. 1989: Observational determination of the greenhouse effect. Nature 342, 758-761.

19. Ramanathan, V., Barkstrom, B.R. \& Harrison, E.F. 1989: Climate and the Earth's Radiation Budget. Physics Today 42 (5), 22-32.

20. Hertzberg M. Colorado, USA. Private communication 2007.

21. Segalstad T. V. and Jaworowski Z. (1991) Carbon isotope mass balance of atmospheric $\mathrm{CO} 2$. unpublished.

22. Petit J. R. Climate and aAtmospheric History of the past 420,000 Years from the Vostok Ice Core, Antarctica. Nature 399: 429-436. 1999.

23. Karlén W. Forskning \& Framtid no 2, 1997 (in Swedish).

24. Anonymous, 2007 Editorial: The hottest year: 1934? Washington Times.

http://washingtontimes.com/article/20070815/editorial/108150004/1013

25. Keenan D. J. (2007) The IPCC and research fraud: the implications.

http://informath.org/apprise/a5620.htm.

Fred Goldberg, Dr Tech (KTH)

Materialdata AB

Box 1210

SE-181 24 Lidingö, Sweden

Fred@materialdata.se 